\title{
Mathematical model to predict methotrexate elimination in children with acute lymphoblastic leukemia
}

\author{
Model matematic de predicţie a modului de eliminare a \\ metotrexatului la copii cu leucemie limfatică acută
}

\author{
Laurenţiu Lucaci $^{1,2}$, Ștefana Maria Moisă ${ }^{1,3}$, Marin Burlea ${ }^{1,3}$, Lucian Miron ${ }^{1,4}$ \\ 1. University of Medicine and Pharmacy "Grigore T. Popa”, Iași \\ 2. Institute of Cardio-vascular Diseases "Prof. Dr. G. Georgescu”, Iași \\ 3. "Sfânta Maria" Emergency Children's Hospital, Iași \\ 4. Regional Oncology Institute, Iași
}

\begin{abstract}
Introduction: Methotrexate, a structural analogue to the folic acid, is one of the most frequently used antimetabolites in pediatric oncologic pathology. Its mode of action and toxic effects are now well known. Material and method: Our study aimed to describe the quantitation of the drug in serum of 40 children with acute lymphatic leukemia receiving high doses of methotrexate and to predict serum methotrexate levels at 96 hours, based on $48 \mathrm{~h}$, $72 \mathrm{~h}$ levels and on alanine aminotransferase (ALT), aspartate aminotransferase (AST), urea, and creatinine serum levels. The above mentioned parameters were analyzed by sampling serum levels at 48h, $72 \mathrm{~h}$ and 96 hours after methotrexate administration and a logical regression model being projected upon obtained results. Results and conclusions: methotrexate serum level at 96 hours does not depend on either AST, ALT, urea, creatinine levels or on the methotrexate level determined at 48 hours, it only depends on the methotrexate serum level at 72 hours.
\end{abstract}

Key words: methotrexate serum level, toxicity

\section{Rezumat}

Introducere: Metotrexatul, analog structural al acidului folic, este unul dintre cel mai frecvent folosiți antimetaboliți în patologia oncologică pediatrică. Modul de acţiune și efectele toxice sunt bine cunoscute $\hat{\imath} n$ prezent. Material şi metoda: Studiul realizat și-a propus să determine profilul eliminării metotrexatului la 40 copii cu leucemie limfatică acută trataţi cu doze mari din acest produs şi să prezică nivelul seric al metotrexatului la 96 ore în funcţie de valorile metotrexatemiei la 48h, 72h, respectiv valorile alaninaminotransferazei ALT, aspartataminotransferazei AST, ale ureei şi creatininei serice. Parametrii menţionaţi au fost analizaţi în probe recoltate la 48, 72 şi 96 ore după administrarea metotrexatului și pe baza rezultatelor obţinute elaborându-se un model de regresie logică. Rezultate şi concluzii: Valoarea metotrexatemiei serice la 96 ore nu depinde de nici una dintre valorile AST, ALT, uree, creatinină, nici de valoarea metotrexatemiei la 48 ore, ci doar de cea înregistrată la 72 ore.

*Corresponding author: Ștefana Maria Moisă, “St. Mary” Emergency Clinical Hospital, Iasi, Vth Pediatrics Clinic, Iasi, Romania, phone: 0740191407, e-mail: stephaniemed@yahoo.com 
Cuvinte cheie: concentraţia serică a metotrexatului, toxicitate

Received: 15 ${ }^{\text {th }}$ May 2013; Accepted: $21^{\text {st }}$ November 2013; Published: 14 ${ }^{\text {th }}$ March 2014.

\section{Introduction}

Methotrexate (MTX) is a widely used antimetabolite in pediatric oncology, effective in acute lymphoblastic leukemia (ALL), non-Hodgkin's malignant lymphoma (NHML), hystiocytosis and osteosarcoma treatment. $(1,2)$

MTX is intermittently administered by oral, intramuscular, subcutaneous, intravenous and intrathecal route. For intravenous administration purpose, a wide range of doses may be used, from a bolus of $10 \mathrm{mg}$ to a $33000 \mathrm{mg} / \mathrm{m}^{2}$ over 20 hours. A high dose is defined as being greater than $500 \mathrm{mg} / \mathrm{m}^{2}$. (3) Usual intravenous perfusion doses of $100-300 \mathrm{mg} / \mathrm{m}^{2}$ must be followed by leucovorin (5-formyl-5,6,7,8 tetrahydrofolate $=$ folinic acid, sometimes still known as citrovorum factor) administration, in order to prevent severe toxicity (4). Reduction of leucovorin to its active compound 5 methyl-tetrahydrofolate makes it to behave as a vitamin, allowing purines and thymidine synthesis to proceed, at least to some degree. On the other hand, as this reduction does not need the action of the hepatic dihydrofolate reductase (DHFR), the vitamin activity of leucovorin is not affected by the inhibitors of DHFR, as MTX (5).

\section{Mechanism of action}

Folic acid (pteroyl-L-glutamic acid = vitamin B9) (in its reduced form of tetrahydrofolate) is a necessary cofactor for thymidine and purines synthesis. Hepatic DHFR is the enzyme that is responsible for dihydrofolate conversion to tetrahydrofolate active form. MTX is a structural analogue of dihydrofolic acid, which results from the substitution of a hydroxyl group with an amino group in the $4^{\text {th }}$ position of the pteridine ring of dihydrofolic acid (MTX $=4$-ami- no, 10 methyl folic acid). MTX enters the cell either by competing for a folate transmembrane carrier, or even by direct diffusion, at high plasma concentrations. (6) A series of four enzymes are inhibited by MTX: dihydrofolate reductase (DHFR), thymidilate synthetase, methylene tetrahydrofolate reductase and the 5 -amino imidazole 4-carboxamide ribonucleotide transformilase (AICAR). The inhibition of those enzymes result in the reduction of the synthesis of tetrahydrofolate (THF), deoxythymidine monophosphate, 5-methyl THF and monophosphate inosine, respectively. A critical determinant of MTX cytotoxicity is the rate of thymidilate synthesis, because the synthesis of thymidilate from uridilate is the only reaction that oxidates tetrahydrofolate to the inactive form, dihydrofolate $(7,8)$.

Another determinant factor is intracellular MTX concentration that exceeds the number of DHFR binding sites, because the intracellular levels of this target enzyme are 20-30 times higher than those necessary to maintain tetrahydrofolate reserve (9).

Both natural folate and MTX are metabolized by folipolyglutamate synthetase to polyglutamic derivatives that cannot escape the cell. The synthesis of MTX polyglutamate enhances drug cytotoxicity, by allowing MTX intracellular accumulation and retention, even after extracellular drug is eliminated.

MTX polyglutamates are stronger DHFR inhibitors than MTX and directly inhibit other thymidine and purine synthesis pathways. ALL pediatric patients that have received high dose MTX in several studies as induction therapy have had higher lymphoblastic MTX concentrations that those who received small dose therapy (10). The lymphoblasts of children with a good prognosis (young age, small white blood 
cell count, female sex) tend to accumulate MTX polyglutamate more efficiently than the lymphoblasts of high risk patients, suggesting that acute lymphoblastic leukemia in small risk patients may be more sensitive to MTX antileukemic effects $(11,12)$.

\section{Metabolism and toxicity}

The plasma clearance of MTX has three phases. The first one is the consequence of a rapid distribution in tissues, the second one is the renal clearance (with a half-time of about 3 hours), and the last one is the elimination phase (with a half time of 8-12 hours). MTX is primarily eliminated by renal excretion, undergoing glomerular filtration and tubular reabsorption and secretion. About $70-90 \%$ of the dose is excreted unmodified into the urine, especially during the first 6 hours. Renal MTX clearance may exceed creatinine clearance. In patients with significant renal dysfunction, MTX clearance is delayed, plasma MTX concentrations remain high or increase, leading to prolonged exposure and severe toxicity. High dose MTX should not be administered to patients with creatinine clearance below 50$70 \%$ of normal. Small dose MTX therapy should also be stopped in patients with serum creatinine above $2 \mathrm{mg} / \mathrm{dl}$ (13). Unfortunately, renal failure induced by MTX is usually non-oliguric, so the early diagnosis must rely on creatinine and creatinine clearance monitoring, as to be able to give leucovorin as early as possible, if one wants the rescue treatment to be useful. Any renal failure suspect patient undergoing MTX treatment should be closely monitored and should receive leucovorin in case when drug clearance is delayed (14). In such cases, patient hydration (3 liters / square meter x 24 hours), urine alkalinization $(50 \mathrm{mEq} \mathrm{NaHCO} / 1$ liter of infused fluid) (both begun prior to and continued after MTX infusion) and avoidance of unnecessary concurrent nephrotoxic agents is recommended, as well. Types of toxicity depend not only on the
MTX dose, but also on the duration of the exposure (15). High concentration - short time exposure to MTX may result in acute renal failure, central nervous system toxicity, or liver damage. Low concentration - long time duration exposure to MTX may result in bone marrow suppression and gastrointestinal epithelial damage. However, regarding the risk of MTX toxicity, the high dose is always of more concern than the duration of the treatment (16).

Drugs able to displace MTX from the plasma proteins clearly increase its toxicity (e.g. non-steroidal anti-inflammatory drugs, sulfonamides), so concomitant use of such medication is strongly discouraged. MTX retention in large extravascular fluid collections, like ascites or pleural effusion, is associated with a prolongation of the half-life, as a result of slow release of the previously retained drug into the blood flow. This prolonged drug exposure may increase toxicity (17).

The damage caused by very high doses of MTX cannot be reversed by leucovorin, whatever its rescue dose may be (18).

Dialysis has only limited value in recovering the acute renal toxicity induced by MTX. Carboxypeptidase $\mathrm{G}_{2}\left(\mathrm{CPDG}_{2}\right)$ is an enzyme which hydrolyzes and thus discards the glutamate remainder from the folic acid and from its natural and synthetic analogues, or antagonists. As a consequence, $\mathrm{CPDG}_{2}$ not only rapidly lowers the concentration of MTX (by way of degrading it to 2,4 diamino $\mathrm{N}_{10}$ methylpteroic acid DAMPA), but also inactivates the leucovorin and its active metabolite, 5-methyl tetrahydrofolate, so leucovorin infusion must be continued, if this new approach to the MTX toxicity rescue is to be used (19).

Low-dose MTX is usually eliminated unchanged by a normal kidney, without significant by-products (20).

The higher the dose, the more likely the metabolization of MTX is. At high-dose reg- 
imen, MTX has two metabolites: one inactive: 2,4-diamino- $\mathrm{N}_{10}$-methylpteroic acid DAMPA (generated by the bacterial carboxypeptidase in the bowels) and one active: 7-hydroxy-MTX (generated by the hepatic aldehyde oxidase). Even if the intrinsic toxicity of 7-hydroxy-MTX is considered to be much lower than that of the parent compound, plasma concentrations of 7-hydroxy-MTX may be equivalent or even exceed MTX concentrations, several hours after high dose MTX infusion, probably because of the slower clearance of this metabolite (21). 7-hydroxi-MTX uses the same transmembrane transport system as MTX and folates and is also subject to polyglutamation. Once polyglutamation is completed, 7-hydroxy-MTX seems able to bind to and inhibit DHFR, contributing to the MTX action and toxicity (22). MTX clearance is not significantly altered by hepatic dysfunction, but MTX dosage reduction in patients with abnormal liver tests is indicated.

The total metabolic and renal clearance of MTX is approximately $100 \mathrm{ml} / \mathrm{min} / \mathrm{m}^{2}$, but it may vary. In patients with normal creatinine clearance, there is not a good correlation between MTX and creatinine clearance. Tubular renal dysfunction, which is not measured by creatinine clearance, may be the cause of this phenomenon. A small test dose of MTX may more accurately predict the kinetics and steady-state concentration of a high dose intravenous MTX perfusion. Best management practice dictate that every high dose MTX administration must be closely watched by renal function and plasma MTX concentration monitoring, in order to determine the dose and duration of leucovorin administration (23).

Our study aimed to describe the quantization of the drug in serum of children with ALL receiving high doses of methotrexate and to elaborate a logical regression in order to predict MTX values at 96 hours based on MTX values at 48 and 72 hours and on the levels of AST, ALT, urea and creatinine.

\section{Material and method}

The study group consisted of 40 patients with ages varying from 2 years and 3 months to 17 years and 8 months, diagnosed with ALL, undergoing treatment regimens that included MTX administration. All children were hospitalized in the Hemato-Oncology Ward of the IVth Pediatric Clinic of the "Saint Mary" Emergency Children's Hospital in Iasi.

\section{Study inclusion criteria:}

1. Confirmed ALL diagnosis

2. Patient undergoing MTX treatment

3. Patient with no liver or kidney dysfunction previously documented or documented at the time of the study.

MTX administration protocol in ALL treatment includes the determination of serum MTX levels. If the value at 48 hours is higher than 0.15 $\mathrm{mmol} / \mathrm{l}$, leucovorin is administered in order to diminish MTX toxicity and MTX level is measured again at 72 hours; if the 72 hours value is below $0.15 \mathrm{mmol} / \mathrm{l}$, the toxic risk is considered to be acceptable, if not, another leucovorin dose is administered.

After MTX is administered, liver and kidney function parameters were measured: aspartate aminotransferase (AST), alanine aminotransferase (ALT), urea and creatinine. MTX serum levels are determined at 48h, $72 \mathrm{~h}$ and 96 hours.

MTX serum levels were measured using Abbott TDxFLx analyzer, which uses fluorescent polarization, radiant energy attenuation, competitive linkage immunoanalysis and endpoint nefelometry technologies.

In order to determine the behavior of the analyzed parameters, we have analyzed the database using SPSS 16.0. First, we identified 
the descriptive statistics parameters (medium, standard deviation, variance, median, minimum and maximum values) for included variables. Then we categorized MTX values according to the four predetermined categories regarding substance elimination. We have calculated the corresponding frequency distributions and we built a logistic multinomial regression to predict MTX serum values at 96 hours based on $48 \mathrm{~h}$ and $72 \mathrm{~h}$ levels, AST, ALT, urea and creatinine levels. We allocated each patient to one of the following MTX elimination categories: fast, intermediate, slow and very slow, based on MTX $72 \mathrm{~h}$ value. The model correctness was evaluated using the standard goodness-of-fit tests and calculating the Cox and Snell, Nagelkerke and McFadden approximations for the coefficient of determination.

\section{Results}

MTX serum levels were pathological in $66.7 \%$ of children at 48 hours, in $7.5 \%$ of children at 72 hours and in $2.5 \%$ of children at 96 hours (Table I). Determinations were performed at $48 \mathrm{~h}, 72 \mathrm{~h}, 96 \mathrm{~h}$ and $120 \mathrm{~h}$ (Supplementary data available in electronic version published on the journal's website: www.rrml.ro). Values at 48h, $72 \mathrm{~h}, 96 \mathrm{~h}$ and $120 \mathrm{~h}$ were determined only if the value previously determined exceeded the threshold of $0.15 \mathrm{mmol} / \mathrm{l}$, in order to monitor toxicity and determine if further leucovorin administration is necessary.

Table I: MTX serum levels in pediatric ALL patients at $48 \mathrm{~h}, 72 \mathrm{~h}$ and 96 hours after drug administration

\begin{tabular}{|c|c|c|c|c|c|}
\hline & \multicolumn{2}{|c|}{$\leq 0.15 \mathrm{mmol} / \mathrm{l}$} & \multicolumn{2}{|c|}{$>0.15 \mathrm{mmol} / \mathrm{l}$} & Total \\
\hline МТX-48h & 12 & $33.3 \%$ & 24 & $66.7 \%$ & 36 \\
\hline MTX-72h & 33 & $91.7 \%$ & 3 & $8.3 \%$ & 36 \\
\hline MTX-96h & 35 & $97.2 \%$ & 1 & $2.8 \%$ & 36 \\
\hline
\end{tabular}

The multinomial logistic regression model we built fits adequately the data set, as it was showed by the goodness-of-fit tests (Chi-square $=100.374, \mathrm{p}=0.000)$. The Cox and Snell, Nagelkerke and McFadden approximations of determination coefficient $\mathrm{R}^{2}$, are very close to 1 (having the values $0.833,1.000$ and respectively 1.000), fact that shows that a significant amount from the variance of the dependent variable is explained by the model.

The regression model results are showed in Table II, which quantifies the effect of each ana-

Table II. The regression model results in predicting the MTX $96 \mathrm{~h}$ value based on $48 \mathrm{~h}$ and $72 \mathrm{~h}$ MTX values, AST, ALT, urea and creatinine serum levels

\begin{tabular}{|c|c|c|c|c|c|c|c|}
\hline \multicolumn{8}{|c|}{ Parameter Estimates Tables } \\
\hline \multirow[b]{2}{*}{ Predictors } & \multirow[b]{2}{*}{ Estimate } & \multirow[b]{2}{*}{ Std. Error } & \multirow[b]{2}{*}{ Wald } & \multirow[b]{2}{*}{ df } & \multirow[b]{2}{*}{ Sig. } & \multicolumn{2}{|c|}{ 95\% Confidence Interva } \\
\hline & & & & & & $\begin{array}{l}\text { Lower } \\
\text { Bound }\end{array}$ & $\begin{array}{l}\text { Upper } \\
\text { Bound }\end{array}$ \\
\hline MTX48h & 1.214 & 3.515 & 0.119 & 1 & 0.730 & -5.675 & 8.104 \\
\hline MTX72h & 36.144 & 14.427 & 6.277 & 1 & 0.012 & 7.869 & 64.420 \\
\hline AST & 0.019 & 0.166 & 0.013 & 1 & 0.908 & -0.307 & 0.345 \\
\hline ALT & 0.005 & 0.109 & 0.002 & 1 & 0.967 & -0.210 & 0.219 \\
\hline Urea & -1.150 & 9.314 & 0.015 & 1 & 0.902 & -19.406 & 17.105 \\
\hline Creatinine & -0.045 & 9.232 & 0.000 & 1 & 0.996 & -18.140 & 18.050 \\
\hline
\end{tabular}


lyzed predictor. We identified a single significant predictor, which is MTX level at 72 hours - this is the only parameter which influences significantly the evolution of MTX level at 96 hours. The other parameters taken in consideration do not have significant influences over the final values of MTX levels at $96 \mathrm{~h}$ or 120 hours.

\section{Discussion}

MTX exposure is important for the prognosis of acute lymphoblastic leukemia patients. The antileukemic activity of MTX is determined by leukemic cell exposure to this drug and the serum level of MTX (24-26).

In our study group delayed MTX elimination is not caused by the standard causes like renal or hepatic dysfunction. The absence of such pathologies was one of the study inclusion criteria. Moreover, none of the patients underwent treatment with substances known to prolong MTX elimination time, like those that interfere with MTX excretion by tubular secretion competition (probenecid, salicylates, indomethacin, ketoprofen, ibuprofen). Nephrotoxic drugs, like aminoglycosides and cisplatin may also alter MTX clearance, but they were not administered to the children, neither.

High plasma concentrations of methotrexate cause gastrointestinal toxicity (27), cerebral toxicity (28), mucositis (29) and myelosuppresion (30). MTX renal toxicity has 3 mechanisms:

1. Allergic, leading to interstitial nephritis, in which case MTX administration is forbidden.

2. Pharmacological toxicity

3. Renal tubes precipitation.

The renal toxicity of MTX through the latter 2 mechanisms can be partially prevented by aggressive hydration and urine alkalinization (31).

High dose MTX can seldom induce heart arrhythmias (either bradyarrythmias, or ventricular tachyarrythmias). These phenomena are reversible. A second MTX exposure, in smaller doses, does not cause the relapse of these manifestations (32).

The potentially severe adverse effects dictate the need for MTX elimination monitoring in every case. Our study demonstrates the existence of individual variability regarding MTX elimination time and the lack of correlation between persistently elevated MTX serum level and liver or renal dysfunction. This issue is consistent with other published studies, since Joannon et al showed that MTX plasma concentrations does not depend on creatinine clearance. Leucovorin dose calculation based on creatinine clearance may lead to a leucovorin overdose (33). Other studies suggest that fast MTX clearance may be a sign of resistance to MTX. The relatively higher incidence of ALL in children with Down's syndrome is well known. Some observations suggest increased toxicity of MTX in these children (34).

One explanation as to why certain patients always have difficulties in eliminating MTX, despite correct hydration and alkalinization and despite proper leucovorin administration is that they are slow acetylators. These patients have a genetic defect of N-acetyltransferase 2 (NAT 2 ), which plays a key role in the activation and metabolism of certain drugs. The diseases is transmitted in an autosomal recessive manner. In the European population, phenotypes (slow, intermediate and rapid acetylators) have equal distributions. Slow acetylators have mutations in both allele of the gene and have a very slow metabolism capacity, thus being exposed to severe adverse effects because of prolonged exposure to high serum MTX values. In these patients, doses should be reduced by $20-50 \%$ and two or more drugs using the same elimination pathway should not be administered (35). Intermediate acetylators are heterozygote patients, who may receive the respective compounds in small doses, with the same precautions. Rapid acetylators 
have a normal metabolism of MTX and may receive standard doses. Acetaminophen inhibits NAT2, while retinoic acid is a NAT2 inductor. In order to reduce MTX toxicity, leucovorine $\left(\mathrm{C}_{20} \mathrm{H}_{21} \mathrm{CaN}_{7} \mathrm{O}_{7}\right)$ is administered based on MTX serum levels, $15 \mathrm{mg}$ every 6 hours, 10 doses, and in case of slow MTX elimination, more doses until MTX levels decrease under the critical threshold. Further genetic studies are needed to prove the veridicity of this hypothesis in the study group.

\section{Conclusions}

The conclusion of the data set analysis shows that serum MTX values 96 hours after administration of standard ALL treatment MTX doses in children does not depend on hepatic or renal parameters if they are normal, nor on MTX serum value at 48 hours; it only depends on MTX serum levels at 72 hours. Children that are known from previous treatment stages to have difficulties eliminating MTX should be closely monitored. Methotrexate clearance seems to be an independent prognostic factor in acute lymphoblastic leukemia in children.

\section{List of abbreviations:}

ALT - alanine aminotransferase

AST - aspartate aminotransferase

MTX - methotrexate

ALL - acute lymphoblastic leukemia

NHML - non-Hodgkin's malignant lymphoma

DHFR - dihydrofolate reductase

THF - tetrahydrofolate

CPDG2 - carboxypeptidase G2

DAMPA - 2,4 diamino $\mathrm{N}_{10}$ methylpteroic acid

NAT2- N-acetyltransferase 2

\section{Statement on the potential conflict of interest:}

All authors declare no conflict of interest.

\section{References}

1. Kamps WA, van der Pal-de Bruin KM, Veerman AJ, Fiocco M, Bierings M, Pieters R. Long-term results of Dutch Childhood Oncology Group studies for children with acute lymphoblastic leukemia from 1984 to 2004. Leukemia. 2010;24(2):309-19 DOI: 10.1038/ leu.2009.258

2. Kampen KR. The discovery and early understanding of leukemia. Leuk Res. 2012;36(1):6-13. DOI: 10.1016/j. leukres.2011.09.028

3. Mantadakis E, Cole PD, Kamen BA. High-dose methotrexate in acute lymphoblastic leukemia: where is the evidence for its continued use? Pharmacotherapy. 2005;25(5):748-55.DOI: 10.1592/phco.25.5.748.63584

4. Sterba J, Valík D, Bajciová V, Kadlecová V, Gregorová V, Mendelová D. High-dose methotrexate and/or leucovorin rescue for the treatment of children with lymphoblastic malignancies: do we really know why, when and how? Neoplasma. 2005;52(6):456-63.

5. Silverman LB, Stevenson KE, O'Brien JE, Asselin BL, Barr RD, Clavell L et al.: Long-term results of Dana-Farber Cancer Institute ALL Consortium protocols for children with newly diagnosed acute lymphoblastic leukemia (1985-2000). Leukemia. 2010;24(2):320-34. DOI: $10.1038 /$ leu.2009.253

6. Veerman AJ, Hählen K, Kamps WA, Van Leeuwen EF, De Vaan GA, Solbu G, et al. High cure rate with a moderately intensive treatment regimen in non-high-risk childhood acute lymphoblastic leukemia. Results of protocol ALL VI from the Dutch Childhood Leukemia Study Group. J Clin Oncol. 1996;14(3):911-8.

7. Salzer WL, Devidas M, Carroll WL, Winick N, Pullen J, Hunger SP et al. Long-term results of the pediatric oncology group studies for childhood acute lymphoblastic leukemia 1984-2001: a report from the Children's Oncology Group. Leukemia. 2010;24(2):355-70. DOI: 10.1038/leu.2009.261

8. Pui CH, Pei D, Sandlund JT, Ribeiro RC, Rubnitz JE, Raimondi SC et al. Long-term results of St Jude Total Therapy Studies 11, 12,13A, 13B, and 14 for childhood acute lymphoblastic leukemia. Leukemia. 2010;24(2):371-82. DOI: 10.1038/leu.2009.252

9. Matloub Y, Bostrom BC, Hunger SP, Stork LC, Angiolillo $\mathrm{A}$, Sather $\mathrm{H}$, et al. Escalating intravenous methotrexate improves event-free survival in children with standard-risk acute lymphoblastic leukemia: a report from the Children's Oncology Group. Blood. 2011;118(2):243-51. DOI: 10.1182/ blood-2010-12-322909

10. Mahoney DH Jr, Shuster JJ, Nitschke R, Lauer S, Steuber CP, Camitta B. Intensification with intermediate-dose intravenous methotrexate is effective therapy for children with lower-risk B-precursor acute lymphoblastic leukemia: A Pediatric Oncology Group study. J Clin Oncol. 2000;18(6):1285-94. 
11. Schmiegelow K, Forestier E, Hellebostad M, Heyman M, Kristinsson J, Soderhall S et al. Long-term results of NOPHO ALL-92 and ALL-2000 studies of childhood acute lymphoblastic leukemia. Leukemia. 2010;24(2):345-54. DOI: 10.1038/leu.2009.251

12. Mitchell C, Richards S, Harrison CJ, Eden T. Long-term follow-up of the United Kingdom medical research council protocols for childhood acute lymphoblastic leukaemia, 1980-2001. Leukemia. 2010;24(2):406-18. DOI: $10.1038 /$ leu.2009.256

13. Evans WE, Relling MV, Rodman JH, Crom WR, Boyett JM, Pui CH. Conventional compared with individualized chemotherapy for childhood acute lymphoblastic leukemia. New Engl J Med. 1998;338(8):499-505. DOI: 10.1056/NEJM199802193380803

14. Mahoney DH, Shuster J, Nitschke R, Lauer SJ, Winick N, Steuber CP, et al. Intermediate-dose intravenous methotrexate with intravenous mercaptopurine is superior to repetitive low-dose oral methotrexate with intravenous mercaptopurine for children with lower-risk B-lineage acute lymphoblastic leukemia: a Pediatric Oncology Group phase III Trial. J Clin Oncol. 1998;16(1):246-54.

15. Camitta B, Mahoney D, Leventhat B, Lauer SJ, Shuster JJ, Adair S, et al. Intensive intravenous methotrexate and mercaptopurine treatment of higher-risk non-T, non-B acute lymphocytic leukemia: a Pediatric Oncology Group study. J Clin Oncol. 1994;12(7):1383-9.

16. Camitta B, Leventhal B, Lauer S, Shuster JJ, Adair S, Casper J, et al. Intermediate-dose intravenous methotrexate and mercaptopurine therapy for non- $\mathrm{T}$, non-B acute lymphocytic leukemia of childhood: a Pediatric Oncology Group study. J Clin Oncol. 1989;7(10):153944.

17. Möricke A, Zimmermann M, Reiter A, Henze G, Schrauder A, Gadner $\mathrm{H}$ et al. Long-term results of five consecutive trials in childhood acute lymphoblastic leukemia performed by the ALL-BFM study group from 1981 to 2000. Leukemia. 2010;24(2):265-84. DOI: 10.1038/leu.2009.257

18. Ahmed YA, Hasan Y. Prevention and Management of High Dose Methotrexate Toxicity. J Cancer Sci Ther 2013;5(3):106-12. DOI: 10.4172/1948-5956.1000193

19. Le Guellec C, Blasco H, Benz J, Hulin A. Therapeutic drug monitoring of methotrexate after its administrations in high-dose protocols. Therapie. 2010;65(3):1639. DOI: $10.2515 /$ therapie/2010016

20. Perazella MA, Moeckel GW. Nephrotoxicity from chemotherapeutic agents: clinical manifestations, pathobiology, and prevention/therapy. Semin Nephrol. 2010;30(6):570-81. DOI: 10.1016/j.semnephrol.2010.09.005

21. Evans WE, Crom WR, Abromowitch M, Dodge R, Look AT, Bowman P, et al. Clinical pharmacodynamics of high-dose methotrexate in childhood acute lymphocytic leukemia. Identification of a relation between concentration and effect. New Engl J Med. 1986;314(8):471-7. DOI: 10.1056/NEJM198602203140803

22. Panetta JC, Wall A, Pui CH, Relling MV, Evans WE. Methotrexate Intracellular Dispositionin Acute Lymphoblastic Leukemia.A Mathematical model of $\gamma$-Glutamyl Hydrolase Activity. Clin Cancer Res. 2002;8(7):2423-9.

23. Asselin BL, Devidas M, Wang C, Pullen J, Borowitz MJ, Hutchinson $\mathrm{R}$ et al. Effectiveness of high-dose methotrexate in T-cell lymphoblastic leukemia and advanced-stage lymphoblastic lymphoma: a randomized study by the Children's Oncology Group (POG 9404). Blood. 2011;118(4):874-83. DOI: 10.1182/ blood-2010-06-292615

24. Bertino JR, Goker E, Gorlick R, Li WW, Banerjee D. Resistance mechanisms to methotrexate in tumors. Oncologist. 1996;1(4):223-6.

25. Matherly LH, Taub JW. Methotrexate pharmacology and resistance in childhood acute lymphoblastic leukemia. Leuk Lymphoma. 1996;21(5-6):359-68. DOI: 10.3109/10428199609093433

26. Gorlick R, Goker E, Trippett T, Watham M, Banerjee D, Bertino JR. Intrinsic and acquired resistance to methotrexate in acute leukemia. New Engl J Med. 1996;335(14):1041-8. DOI: 10.1056/ NEJM199610033351408

27. Farrow AC, Buchanan GR, Zwiener RJ, Bowman WP, Winick NJ. Serum aminotransferase elevation during and following treatment of childhood acute lymphoblastic leukemia. J Clin Oncol. 1997;15(4):1560-6.

28. Moe PJ, Holen A.: High-dose methotrexate in childhood acute lymphoblastic leukemia. Pediatr Hematol Oncol 2000;17(8):615-22. DOI: 10.1080/08880010050211321

29. Maiquma T, Hayashi Y, Ueshima S, Kaji M, Eqawa $\mathrm{T}$, Chayama T, et al. Relationship between oral mucositis and high-dose methotrexate in pediatric acute lymphoblastic leukemia. Int J Clin Pharmacol Ther. 2008;46(11):584-90. DOI: 10.5414/CPP46584

30. Xu WQ, Tang YM, Fanq CQ, Song H, Shi SW, Yang $\mathrm{SL}$, et al. Study on elimination delay in high-dose methotrexate in children with acute lymphoblastic leukemia. Zhonghua Xue Ye Xue Za Zhi. 2005;26(1):15-8.

31. Isoda T, Ito S, Kajiwara M, Nagasawa M. Successful high-dose methotrexate therapy in a patient with acute lymphoblastic leukemia who developed acute renal failure during initial treatment. Pediatr Int. 2007;49(6):1018-9. DOI: 10.1111/j.1442200X.2007.02461.x

32. Perez-Verdia A, Angulo F, Hardwicke FL, Nugent KM. Acute cardiac toxicity associated with high-dose intravenous methotrexate therapy: case report and review of the literature. Pharmacotherapy. 2005:25(9):1271-6. DOI: $10.1592 /$ phco.2005.25.9.1271

33. Joannon P, Oviedo I, Campbell M, Tordecilla J. High- 
dose methotrexate therapy of childhood acute lymphoblastic leukemia: lack of relation between serum methotrexate concentration and creatinine clearance. Pediatr Blood Cancer. 2004;43(1):17-22. DOI: 10.1002/ pbc. 20032

34. Borsi JD, Moe PJ. Systemic Clearance of Methotrexate in the Prognosis of Acute Lymphoblastic Leuke- mia in Children. Cancer. 1987;60(12):3020-4. DO I:2/1097-0142(19871215)60:12<3020::AID-CNCR2820601227>3.0.CO;2-0

35. Hein DW, Doll MA. Accuracy of various NAT 2 SNP genotyping panelsto infer rapid, intermediateand slow acetylator phenotypes. Pharmacogenomics. 2012;13(1):31-41. DOI: 10.2217/pgs.11.122 